УДК 340.132.6

DOI https://doi.org/10.32849/2663-5313/2020.4.39

\title{
Валерія Антошкіна,
}

канд. юрид. наук, доцент,

дочент кафедри галузевих юридичних дисциплін

Бердянського університету менеджменту і бізнесу

\section{ОЗНАКИ ТА ОСОБЛИВОСТІ ПРАВА, ЯКІ ЗУМОВЛЮЮТЬ НЕОБХІДНІСТЬ ТЛУМАЧЕННЯ}

У загальній теорії права розроблено базові підходи щодо тлумачення норм, але вони потребують більш пильної уваги та удосконалення, особливо на сучасному етапі розвитку нашого суспільства в умовах постійного оновлення нормативного матеріалу. Саме тому підстави тлумачення, в тому числі з урахуванням особливостей різних галузей права та законодавства, стали об'єктом розгляду в даній статті. Автор наводить думки вчених-правознавиів щодо причин, які зумовлюють необхідність тлумачення правових приписів. Погоджуючись з наведеними твердженнями та висновками, вважає за доиільне проаналізувати вказані підстави більш докладно та доповнити їх. $У$ статті зроблено висновок, що причини виникнення необхідності в застосуванні тлумачення можна поділити на дві групи: об'єктивні - не можна усунути і не можна трактувати як провина законодавия (3'ясування волі законодавия, яка може мінятися з часом, з'ясування будь-якої форми мови, яка має певну автономність від думки, абстрактний характер норм права, з'ясування спеиіальних термінів та ін.); суб'єктивні - результат упущень суб'єктів правотворчості, які у разі належного ставлення могли бути усунені під час створення нормативно-правового акта (погана редакиія тексту нормативного акта, відсутність спеиіальних знань автора нормативного акта, наявність колізій між нормативними актами, що регулюють одне питання, невміле застосування правил правотворчої техніки та ін.). Також зауважується, що, здійснюючи тлумачення, інтерпретатор права має враховувати особливості режиму правового регулювання, основні засади, принципи і підходи до викладення норм тієі чи іншої галузі права та ін. Ці проблеми і вирішують за допомогою різних видів тлумачення правових норм. Як показує проведене дослідження, причини необхідності тлумачення юридичних норм пов'язані не лише з прорахунками, допущеними законодавием у формулюваннях текстів законів, їх невдалістю, неточністю, нечіткістю і $\mathrm{m}$. $n$. Тому вдосконалення законодавства, усунення правотворчих помилок не призводить до втрати ролі тлумачення права в проиесі його реалізаиії. Більше того, чим досконаліше чинне законодавство, тим вдумливішим має бути тлумачення його приписів. Адже досконалий закон завжди має дуже високу міру абстрактності закріплених у ньому правил поведінки, що робить актуальними подальші наукові пошуки в даній сфері.

Ключові слова: особливості тлумачення, об'єктивні причини тлумачення, суб'єктивні причини тлумачення, оцінні поняття в праві, галузеві особливості тлумачення.

Постановка проблеми. Ефективність правового регулювання значною мірою залежить від чіткості та зрозумілості правових приписів, їхньої системності та взаємної узгодженості. Проте законотворчий процес завжди пов'язаний із фрагментарністю зміни нормативних положень та існуванням часових проміжків у реалізації законотворчої ініціативи. Усе це спричиняе нечіткість нормативних приписів та відповідну необхідність їх подальшого тлумачення правозастосовчими органами та теоретиками права. Дослідження та розуміння причин, які зумовлюють необхідність тлумачення з урахуванням особливостей різних галузей права, дозволить удосконалити не тільки правоінтерпретаційний, а й нормотворчий, правозастосовний процеси.
Аналіз останніх досліджень та публікацій. Проблеми тлумачення правових норм висвітлювались у працях вітчизняних i зарубіжних науковців, таких як: С. С. Алексєєв, У. Бернам, Є. В. Васьковський, О. Б. Венгеров, М. О. Власенко, Ю. Л. Власов, М. М. Вопленко, О. В. Капліна, П. О. Недбайло, А. С. Піголкін, П. М. Рабінович, Б. Спасов, А. О. Селіванов, І. Д. Сліденко, В. Я. Тацій, Ю. М. Тодика, Г. О. Христова, О. Ф. Черданцев, Ю. С. Шемшученко та ін. Проте питання про підстави, які викликають необхідність тлумачення, потребує детальнішого вивчення.

Мета статті. У загальній теорії права розроблено базові підходи щодо тлумачення 
норм, але вони потребують більш пильної уваги та удосконалення, особливо на сучасному етапі розвитку нашого суспільства в умовах постійного оновлення нормативного матеріалу. Саме тому підстави тлумачення, в тому числі з урахуванням особливостей різних галузей права та законодавства, стали об'єктом розгляду в даній статті.

Виклад основного матеріалу. У науковій літературі висловлювалися різні думки щодо причин, які зумовлюють необхідність тлумачення правових приписів. Л. Н. Александрова так пояснює це явище: 1) норми права, що містяться в нормативних актах, виражаються за допомогою слів, пропозицій, формулювань, для розуміння сенсу яких, значення і логічного зв'язку між ними потрібна розумова діяльність; 2) у нормативних актах воля держави виражена через засоби і прийоми юридичної техніки, що потребує для правильного їх пояснення спеціальних юридичних знань; 3) мова закону не спрямована на конкретну особу, текст закону відрізняється безособовістю викладу, стислістю формулювань, а також великою формалізацією, що веде до частого виникнення у правозастосувача необхідності розшифровування цих формулювань, 4) недосконалість і неадекватне використання законодавчої техніки $[1$, c. 21]

Г. О. Саміло виокремлює дещо інші ознаки й особливості норм права, які викликають необхідність тлумачення:

1. Норми права мають загальний і абстрактний характер, коло їхньої дії поширюється на велику кількість суб'єктів і ситуацій, але разом із тим реалізуються в конкретних діях осіб у конкретних випадках. Отже, виникає потреба наблизити формальне правило його до конкретних дій суб'єкта та ситуацій.

2. Кожна норма права регулює певний вид суспільних відносин, окреслений у ній загальними рисами. Конкретні відносини, які регулює норма права, є вельми численними. Вони мають індивідуальні особливості і водночас суттєві риси, характерні для всіх видів відносин. Ця обставина в процесі реалізації норм права породжує багато питань, що належать до змісту норм права, відповіді на які можна отримати лише шляхом тлумачення

3. Норми права діють досить тривалий час. У період їх дії у результаті розвитку економічних та суспільних відносин виникають нові ситуації, які підпадають під регулювання певних норм права в силу їх загального характеру.

4. Норми права мають певну мовнологічну зовнішню форму, особливості якої потребують тлумачення.
5. Логічні форми не тотожні граматичним, логіка не зливається 3 граматикою. Слово не дає повного уявлення про сутність речі, яку воно означає, слова не мають єдиної інтерпретації. Зв'язок між словом і поняттям ускладнюється тим, що значення слова в мові охоплює не весь зміст поняття, а лише загальновідому його частину, і тут слово опиняється в своєму значенні вужчим за поняття.

6. Суб'єкти суспільних відносин належать до різних соціальних верств, професій, мають різний життєвий досвід, різну правову і моральну свідомість, сприймають однакові явища дійсності з різним ступенем точності, широти і глибини [2, с. 11-13].

3 вищенаведеними думками та висновками можна повністю погодитися, разом із тим вважаємо за доцільне роздивитися вказані підстави більш докладно та доповнити їх.

Отже, можемо таким чином окреслити ті явища правової дійсності, які є визначальними для процесу тлумачення в праві та мають бути враховані особами, що здійснюють правоінтерпретаційну діяльність.

1. Однією з основних причин, що зумовлює необхідність тлумачення у сфері права, $\epsilon$ загальний характер правових норм. Будьяка норма права $€$ загальним правилом поведінки в певній сфері соціальних відносин. Встановлюючи таке загальне правило, «видавець норми» не може передбачити усі нюанси відносин, що виникають під час ії застосування. Тобто йдеться про неповне охоплення юридичними нормами фактичних умов життя. Тому нерідко для того, щоб норма права почала реально діяти у процесі регулювання конкретних відносин, потрібно здійснити її тлумачення, яке б наближало загальне правило до конкретного випадку.

Наприклад, під час застосування законодавчих норм про спадковий договір у практиці постало питання щодо форми та виду дій, які набувач за договором має здійснити до або після відкриття спадщини. У процесі вирішення конкретних справ суди визначають, чи можна визначити здійснені набувачем дії як такі, що відповідають вимогам закону.

2. Певною мірою необхідність і особливості тлумачення правових норм зумовлені правовими властивостями самих галузей права, які відображають природу регульованих ними відносин. Дані особливості і властивості відіграють важливу роль у процесі правильного розуміння і застосування норм відповідного законодавства. Значна різниця в підходах залежить від того, приватна чи публічна галузь права. Одним із таких важливих чинників є тип правового регулювання, тобто спосіб сполучення (поєднання) 
юридичних дозволів і заборон, на котрих базується регулювання: загальнодозвільний (грунтується на загальному дозволі) і спеціально-дозвільний (грунтується на загальній забороні) [3, с. 138]. Окрім цього, треба враховувати основні засади кожної галузі права, які або закріплені у відповідному законодавстві, або визначені в науковій літературі на підставі аналізу нормативного матеріалу.

Також якщо йдеться про цивільне, сімейне чи господарське право, то тут $€$ широта сфери їх дії - від відносин фізичних осіб майнового та немайнового характеру до відносин на промисловому ринку. Це веде до розгалуженості і складності законодавства та, відповідно, до необхідності тлумачення під час реалізації норм.

3. Під час написання текстів нормативно-правових актів законодавець нерідко свідомо використовує терміни, які не мають єдиного значення. Такі поняття можуть мати подвійне, а інколи - невизначене коло значень. У сучасних нормативно-правових актах нерідко можна побачити застосування такого правового прийому: в першій статті того чи іншого нормативного акта вказується, що певний термін має відповідне значення «для цілей цього закону». Вказане свідчить про те, що законодавець розуміє обмеженість встановленого ним визначення і розглядає його виключно для певної правової мети - регулювання вказаного виду відносин. Цим він допускає, що в інших відносинах вказаний термін може набувати іншого значення. У статті 14 Податкового Кодексу України № 2755-VI від 02.12.2010 дається роз'яснення термінів, які використовуються в зазначеному нормативно-правовому акті, що є значним за обсягом, як можна визначити 3 нумерації ч. 1 - 3 п. 14.1.1. до п. 14.1.277.

Різне значення семантично однакових термінів інколи спричиняе на практиці багато проблем. В окремих випадках воно тягне за собою необхідність втручання вищих судових органів та здійснення офіційного тлумачення. Зокрема, у разі виникнення конкретних проблем у тлумаченні терміна «член сім'ї» Конституційний Суд України 03 червня 1999 року вимушений був надати його офіційне тлумачення. При цьому він зазначив, що стосовно поняття «член сім'ї» Конституційний Суд України виходить 3 об'єктивної відмінності його змісту залежно від галузі законодавства [4]. Отже, поняття «член сім'ї», що використовується в податковому, житловому, цивільному, сімейному законодавстві,,, може мати різне значення, залежно від мети правового регулюванні вказаних видів відносин.
Вкладання волі законодавця в нормативний правовий акт відбувається за допомогою прийомів юридичної техніки з використанням спеціальної юридичної термінології, юридичних конструкцій і відсилань. Має місце свідоме використання в законодавстві термінів, які не мають єдиного значення. Усе це говорить про необхідність володіння спеціальними знаннями в цій галузі.

4. Необхідність застосування тлумачення спричинена використанням у нормативних актах термінів, які не визначені в законодавстві та мають оціночний характер. Такий прийом юридичної техніки, як включення в текст правових норм оцінних понять, забезпечує гнучкість правового регулювання, дає можливість під час застосування норм врахувати зміни в суспільному житті, що відбуваються в явищах, описаних з їх допомогою. Разом із тим здійснення відповідного тлумачення нормативних положень 3 оцінними поняттями дуже часто вимагають особливих професійних знань і умінь. У цьому випадку підстави для тлумачення мають об'єктивний характер. Зокрема, суди в процесі розгляду конкретних спорів визначають такі поняття, як «істотне порушення договору», «намір завдати шкоду іншій особі», «справедливий розподіл витрат між сторонами», «нормально необхідний час для відповіді», «істотна шкода», «необхідна і достатня шкода», «тяжка шкода», «тяжкі наслідки», «достатні підстави», «явно злочинний наказ або розпорядження», «належні для високопродуктивної роботи умови праці», «вчинок державного службовця, який порочить його як державного службовця або дискредитує державний орган, у якому він працює», «неповна службова відповідність», «ділові якості особи», «виняткові випадки» тощо. Дані приклади оцінних понять з різних галузей права - цивільного, кримінального, адміністративного.

У цьому зв'язку можна дійти закономірного висновку, що, оскільки законодавчо неможливо закріпити зміст оціночної норми права, в процесі правозастосування такої норми існує реальна необхідність виявляти зміст конкретного оціночного поняття шляхом його системного тлумачення і конкретизації.

5. Тлумачення нормативних приписів може пов'язуватися також 3 нечіткістю та суперечливістю наявних нормативних положень. Такі випадки непоодинокі. Їх можна пояснити не об'єктивними, а суб'єктивними факторами - недостатньою «якістю» нормативного матеріалу, упущеннями, які виникають у процесі прийняття законів, відсутністю наукового експертизи проектів нормативних актів тощо. Непоодинокими є випадки, коли 
норми, що містяться навіть в одному нормативному акті, прямо не збігаються. Такі розбіжності правових приписів обов'язково потребують тлумачення, оскільки не можуть вирішуватися однозначно.

На жаль, ця підстава тлумачення є вкрай актуальною для вітчизняної системи законодавства, матеріал щодо цього питання значний за обсягом і потребує окремого розгляду в надалі.

6. Варто зазначити, що складність тлумачення не в останню чергу викликана значним обсягом нормативного матеріалу, а також тим, що об'єктом тлумачення можуть виступати не лише закони і підзаконні акти нашої держави, а й міжнародні договори та звичаї. Адже, згідно 3 положеннями ст. 9 Конституції України, «чинні міжнародні договори, згода на обов'язковість яких надана Верховною Радою України, є частиною національного законодавства України».

7. У рамках даного дослідження доцільним $є$ визначення такої специфічної проблеми тлумачення, як дуалізм приватного права, оскільки маємо два нормативні акти Господарський кодекс України та Цивільний кодекс України. Причому перший не просто не доповнює останній, а й встановлює окреме від Цивільного кодексу правове регулювання таких базових інститутів приватного права, як суб'єкти, речове та договірне право тощо, що не може сприяти адекватному тлумаченню норм.

Зокрема, відсутність у цивілістиці поняття корпоративних прав як майнових та немайнових прав учасників товариства вимагає вироблення відповідної доктрини для оперування ними як об'єктами цивільних прав під час вирішення спорів. Дані положення містяться у господарському законодавстві, що призводить до думки, що вони не є цивільно-правовими і не входять до сфери цивільно-правових відносин. Проте на практиці мають місце численні випадки продажу корпоративних прав приватними особами. У цьому аспекті проблематику питання правильно визначає I. Спасибо-Фатєєва: «як співвідносяться між собою ці права та права учасника господарського товариства (ст. 116 ЦК та ін.), право на частку учасника господарського товариства в статутному (або складеному) капіталі (ст.ст. 143, 147 ЦК та ін.), право участі в товаристві (ст. 100 ЦК), майнове право (ст. 177 ЦК) [5, с. 14-25].

Слушною нам видається позиція І. Л. Свміної: «Дуалізм права не можна підміняти дуалізмом приватного (цивільного) права, де господарське законодавство пропонують розглядати як просте відгалуження від цивільного (пандектного) права і зводити пріоритет до простого пріоритету спеціальної норми щодо загальної» [6, с. 74].

За позицією ВГСУ, викладеною в Інформаційному листі від 7 квітня 2008 р. № 01-8/211, ЦК України та ГК України співвідносяться як загальний та спеціальний закони - у процесі правозастосування застосовується закон не в цілому як нормативноправовий акт, а відповідна правова норма чи іï̈ частина, за змістом якої і визначається, чи є ця норма (ії частина) спеціальною чи загальною. Тому в разі, якщо норми ГК України не містять спеціальних норм, а встановлюють загальні правила, які не узгоджуються з відповідними правилами ЦК України, слід застосовувати правила, встановлені ЦК України.

Так, норми ГК України про недійсність господарських зобов'язань суперечать положенням ЦК України про недійсність правочинів як за термінологією, так і за змістом тому, що не містять особливостей регулювання господарських відносин, а містять загальні правила про недійсність господарських зобов'язань. Тому ст. 207 ГК України відповідно до абз. 1 та 2 ч. 2 ст. 4 ЦК України застосовуватись не може.

Крім того, право є складною взаємопов'язаною системою, в якій кожна правова норма не може працювати сама по собі. Наприклад, у процесі усиновлення застосовується і цивільне право, і процесуальне, і норми сімейного права, які призначені для усіх, але в конкретному випадку працюють для однієї приватної особи.

8. Необхідність тлумачення правових норм зумовлюється також особливістю зовнішнього оформлення норм права. У цьому аспекті слушною нам видається думка С. С. Алексєєва про те, що необхідність тлумачення правового акта випливає з тих самих причин, що зумовлюють необхідність тлумачення будь-якої форми мови [7, с. 291-292]. 3'ясування будь-якого тексту вимагає певної розумової діяльності, тобто дій з розпізнавання знакової системи - слів, речень, їх логічного зв'язку.

До цього слід додати, що норми права формуються і фіксуються через слова і ї поєднання, які використовуються законодавцем, проте «логічні форми не тотожні граматичним, логіка не зливається з граматикою» $[8$, c. 170$]$.

Отже, пояснюється необхідність тлумачення тим, що нормативно-правові акти містять загальні, в деяких випадках абстрактні нормативні положення, викладені не тільки в знаковій системі, мовно-структурному вигляді, але і «юридичною мовою». Усе це вимагає напруженої розумової діяльності, 
із суб'єктивним і об'єктивним використанням юридичних та інших спеціальних знань.

9. Особлива умова, що впливає на процес тлумачення, - вплив міжнародно-правового регулювання. Міжнародні конвенції, договори значно вплинули на формування і зміну правових норм, практику їх застосування. Слід також зазначити, що значний обсяг відносин фізичних і юридичних осіб різних держав регулюються галуззю міжнародного права.

Так, зокрема, міжнародні правила 3 тлумачення торгових термінів «Інкотермс», видані Міжнародною торговою палатою, містять у собі інтерпретації різних юридичних положень, що використовуються учасниками міжнародної торгівлі. Вони є приватною неофіційною кодифікацією міжнародних торгових звичаїв. Уперше опубліковані в 1936 році як збірка тлумачень торгових звичаїв, що найчастіше зустрічаються.

Ці терміни складалися в міжнародній практиці протягом тривалого часу і нарешті отримали статус звичаїв у міжнародної торгівлі. Проте у законодавстві різних країн, а іноді й у портах однієї країни, мали місце суттєві розбіжності щодо змісту торгових термінів. Тому для уніфікації зовнішньоторгового обігу розробили Інкотермс, що дало змогу закріпити однакові правила тлумачення термінів, найчастіше вживаних у зовнішній торгівлі.

За своїм правовим статусом Інкотермс не є джерелом права в об'єктивному сенсі і не виступають як норми права. Вони отримують юридично обов'язкове значення якщо сторони в договорі роблять щодо них expressis verbis посилання. Дана договірна умова матиме зобов'язуючий характер для контрагентів. У цьому випадку Інкотермс виступають як джерело права в суб'єктивному сенсі (суб'єктивні права і обов'язки сторін договору).

10. Об'єктами тлумачення можуть виступати не тільки нормативно-правові акти, а й правочини. Необхідність у тлумаченні договору виникає в разі неповного або не досить ясного формулювання його окремих умов, спростування сторонами або третіми особами його укладення або дійсності, а також його правової природи.

Вирази та слова осіб під час укладення правочинів не завжди однозначно відображають їхню волю. Нерідко під час їх реалізації виникають суперечки щодо змісту окремих положень або умов. Отже, недостатня визначеність умов правочинів, спростування їх наявності, незрозумілість змісту використовуваних понять, необхідність визначення правової природи спричиняють необхідність тлумачення.

11. Системність правових норм зумовлює послідовність у тлумаченні: тлумачення однієї норми веде до необхідності визначення пов'язаної з нею норми, тому що істинний сенс тлумаченого нормативного припису буде зрозумілий тільки після розгляду взаємопов'язаних норм.

12. Необхідність тлумачення норм права іноді випливає зі змісту самого нормативного акта, коли в ньому трапляються вирази «i т. д.», «i т. п.», «інші» тощо. Встановити їх істинне значення можливо тільки за допомогою тлумачення

Загалом причини виникнення необхідності в застосуванні тлумачення можна поділити на дві групи:

- об'єктивні - не можна усунути і не можна трактувати як провина законодавця (з'ясування волі законодавця, яка може мінятися 3 часом, з'ясування будь-якої форми мови, яка має певну автономність від думки, абстрактний характер норм права, з'ясування спеціальних термінів та ін.);

- суб'єктивні - результат упущень суб'єктів правотворчості, які у разі належного ставлення могли бути усунені під час створення нормативно-правового акта (погана редакція тексту нормативного акта, відсутність спеціальних знань автора нормативного акта, наявність колізій між нормативними актами, що регулюють одне питання, невміле застосування правил правотворчої техніки та ін.).

Таким чином, тлумачення правової норми є процесом з'ясування її змісту (сенсу) через усунення виявлених в ній неясностей, які виникають через низку обставин, зокрема через стислість формулювань нормативноправового акта, що зумовлено самою його природою, через появу нових суспільних відносин і життєвих фактів, що не знаходять точних словесних описів у нормативно-правових актах, особливостей режиму правового регулювання та викладення норм тієї чи іншої галузі права та ін. Ці проблеми і вирішують за допомогою різних видів тлумачення правових норм, основні підстави застосування яких нами узагальнено на рис. 1.

Як показує проведене дослідження, причини необхідності тлумачення юридичних норм пов'язані не лише 3 прорахунками, допущеними законодавцем у формулюваннях текстів законів, їх невдалістю, неточністю, нечіткістю і т. п.

\section{Висновки}

Отже, у сфері права широке застосування має процес тлумачення правових норм, існує ціла низка підстав, які спричиняють необхідність здійснення тлумачення правових норм. При цьому слід мати на увазі, особливо законотворцям, що якщо така причина тлумачення, як загальний характер правової норми, випливає 


\begin{tabular}{|c|c|}
\hline \multicolumn{2}{|c|}{ Основні підстави застосування тлумачення } \\
\hline Системність правових норм & $\begin{array}{c}\text { Загальний характер } \\
\text { правової норми }\end{array}$ \\
\hline Широта сфери дії права & $\begin{array}{c}\text { Недосконалість законодавчої } \\
\text { техніки }\end{array}$ \\
\hline $\begin{array}{c}\text { Використання в нормативних } \\
\text { актах оціночних понять }\end{array}$ & $\begin{array}{c}\text { Нечіткість та суперечливість } \\
\text { наявних нормативних положень }\end{array}$ \\
\hline $\begin{array}{c}\text { Використання в законодавстві } \\
\text { термінів, які не мають } \\
\text { єдиного значення }\end{array}$ & $\begin{array}{l}\text { Особливості викладення } \\
\text { нормативного матеріалу }\end{array}$ \\
\hline $\begin{array}{c}\text { Пов'язаність норм права в } \\
\text { нормативних актах } \\
\text { правилами мови }\end{array}$ & $\begin{array}{c}\text { Розширене коло об’єктів } \\
\text { тлумачення }\end{array}$ \\
\hline $\begin{array}{l}\text { Особливості зовнішнього } \\
\text { оформлення норм права }\end{array}$ & $\begin{array}{c}\text { Вплив міжнародно-правового } \\
\text { регулювання }\end{array}$ \\
\hline Дуалізм приватного права & Нормативність права \\
\hline
\end{tabular}

Рис. 1. Основні підстави застосування тлумачення в праві

із самої суті право реалізації, усі інші є значною мірою наслідками недосконалості юридичної техніки і мають поступово усуватися.

Таким чином, судження про необхідність тлумачення права спирається на дуже вагомі аргументи. Причому ця діяльність викликана не лише суб'єктивними, але й об'єктивними причинами. Тому вдосконалення законодавства, усунення правотворчих помилок не спричиняе за собою призводить до втрати ролі тлумачення права в процесі його реалізації. Більше того, чим досконаліше чинне законодавство, тим вдумливішим має бути тлумачення його приписів. Адже досконалий закон завжди має дуже високий ступінь абстрактності закріплених у ньому правил поведінки, що робить актуальними подальші наукові пошуки в даній сфері.

\section{Список використаних джерел:}

1. Александрова Л. Н. Толкование юридических норм и его влияние на судебную практику. Известия Российского государственного педагогического университета им. А. И. Гериена. 2007. № 15 (39). С. 20-24.

2. Саміло Г. О. Проблеми тлумачення правових норм. Запоріжжя: ЗНТУ, 2017. 144 с.

3. Лоскутов Т.О. Щодо типів правового регулювання у кримінальному процесі. Науковий вісник Ужгородського начіональ- ного університету. Серія «Право». 2015. Випуск 30. Том 2. С. 137-140.

4. Рішення Конституційного Суду України від 3 червня 1999 р. у справі за конституційними поданнями Служби безпеки України, Державного комітету нафтової, газової та нафтопереробної промисловості України, Міністерства фінансів України щодо офіційного тлумачення положень пункту 6 статті 12 Закону України «Про соціальний і правовий захист військовослужбовців та членів їх сімей», частини четвертої і п'ятої статті 22 Закону України «Про міліцію» та частини шостої статті 22 Закону України «Про пожежну безпеку» (справа про офіційне тлумачення терміна «член сім'і»). Офіиійний вісник Украӥни. 1999. № 24. Ст. 1122.

5. Спасибо-Фатєєва I. Доктринальне тлумачення. Вісник академї правових наук України. 2005. № 1 (40). С. 14-25.

6. Свміна І. Л. Недійсність договорів за цивільним та господарським законодавством: засади правозастосування. Вісник ОНУ ім. I. І. Мечникова. Серія «Правознавство». 2014. Т. 19. Вип. 2 (23). С. 70-79.

7. Алексеев С. С. Общая теория права : в 2-х томах. Т. 2. Москва, 1982.360 с.

8. Ахматов А. С. Логические формы и их выражение в языке. Мышление и язык. Москва, 1957. 247 с. 
In general theory of law basic approaches to interpreting norms have been developed, but they require more attention to be paid and their improvement, especially at the current stage of development of our society in the conditions of constant updating of normative material. That is why the reasons for interpretation, including the specificities of the various spheres of law and legislation, have become the object of research in this paper. The author mentions the opinions of legal scholars outlined for the reasons that necessitate the interpretation of legal requirements. While agreeing with the statements and conclusions given, it is advisable to analyze these reasons in more detail and to supplement them. The paper concludes that the reasons for the need for interpretation can be divided into two groups: objective - can not be resolved and can not be interpreted as the fault of the legislator (clarification of the will of the legislator, which can be changed over time, clarification of any form of language that has some autonomy from thought, abstract nature of the norms of law, clarification special terms, etc.); subjective - the result of faults by legislators, which, in due regard, could have been eliminated while the creation of a legal act (poor edition of the text of the normative act, lack of special knowledge of the author of the normative act, the presence of conflicts between normative acts which are regulating the same issue, inappropriate usage of the rules of law-making technique, etc.). Attention is also paid to the fact that the subject of interpretation of law while doing it must take into account the peculiarities of the regime of legal regulation, the main grounds, principles and approaches to the statement of the rules of one or another field of law, etc. These problems are being solved with the help of different types of interpretation of legal norms. According to the conducted research, the reasons for the need to interpret legal norms are connected not only with miscalculations made by the legislator in the formulations of the texts of laws, their failure, inaccuracy, discrepancy, etc. Therefore, improving the legislation, eliminating law-making errors does not cause the loss of the role of law interpretation in the process of its implementation. Moreover, the better the current legislation is, the more thoughtful the interpretation of its requirements should be. After all, perfect law always has a very high degree of abstractness of the rules of conduct enshrined in it, which makes relevant further scientific research in this field.

Key words: features of interpretation, objective reasons for interpretation, subjective reasons for interpretation, evaluative concepts in law, sectoral features of interpretation. 